\title{
Whither Interlibrary Loan?
}

Interlibrary loan traffic in academic libraries has doubled in the past five years, with an ever-growing percent of the lending being done by the nation's few largest libraries. Concurrently labor costs have risen substantially so that some large libraries now claim that they are putting $\$ 50,000$ to $\$ 100,000$ per year more into interlibrary lending than they are getting out through borrowing. This growing inequity is forcing discussion of programs-local, regional, and national-for charging fees for interlibrary loan service. This paper raises some of the considerations that should figure into any such discussions.

$\mathrm{T}_{\mathrm{H}}$ brary len lending its books to another is based upon the premise that although books may physically be the chattel of the institution that bought and paid for them, they belong intellectually to the general cultural heritage of mankind and ought somehow to be made available to all men. Interlibrary loan has satisfied this latter characteristic of books while in the former sense the lending library's equity in its books was presumably protected by the reciprocal nature of the practice itself. After all, as many books were borrowed as were lent.

Reciprocity, however, functions effectively as a balancing factor only in the broad middle range of libraries that borrow and lend at roughly the same rates. At one end of the scale there are many small libraries that can be only borrowers, while at the opposite end there are a number of libraries, perhaps a hundred, that lend very many more books than they borrow. ${ }^{1}$ Thus the resources of the latter institutions go to subsidize the system for the benefit of the former.

David Kaser is director of libraries, Cornell University, Ithaca, New York.
Until relatively recently this imbalance caused limited concern among large libraries, because it required of them only a modest supernumerary expenditure above their own operating costs. Their major investment was in the books themselves, and if the normal use expectancy of a book was fifty readings, an occasional interlibrary use of that volume represented a loss to the holding institution of only one-fiftieth of its cost. Labor was cheap, so the staff time required for the internal handling of interlibrary loans was rationalized as a small contribution to the general good.

Libraries, however, have recently become very substantially labor intensive enterprises. By far the largest portion of a library's expenditure today goes into direct payroll; expenditures for the books themselves represent only half as much investment in terms of operating costs as do labor costs. The reversal of this ratio is now forcing recognition and appraisal of the impact of the practice of interlibrary loan on the large primarily lending libraries.

Concurrent with this relocation of library costs from books to labor came another phenomenon that aggravated the long quiescent problem of the large 
library's expenditures on interlibrary lending. This was society's inability any longer to fulfill all of its advanced study and research needs, in that relatively few university centers which were already prepared to furnish out of their own resources the requisite library materials. Suddenly research and advanced study with very large library requirements were going on seemingly everywhere, whether the necessary book resources were available there or not. Traffic in interlibrary loan requests against the few large libraries virtually skyrocketed, ${ }^{2}$ while their own needs to borrow from the system rose less rapidly when indeed they rose at all. The historic inequity thus became greater even than it had been before, although recognition of its debilitating effect upon the lending libraries remained slow in coming. ${ }^{3}$

Reasons for the slowness of the library community to recognize this change have doubtless been varied. One reason is that, just as doctors will let no one die despite his inability to pay, so librarians feel constrained to let no one's need for a book go unmet. Secondly, some large publicly supported institutions have assumed their extra-campus landings to be a mandated service accompanying their tax support, although this argument becomes uncomfortably vague when loans are made outside of the geographical area constituting the tax base. Interlibrary loan furthermore is one service for which librarians have received only praise from the lay public, and no one ever likes to relinquish a practice that others think he performs well. In the final analysis, however, the main reason is probably that the full magnitude of the costs of interlibrary lending have seldom really been recognized by librarians themselves.

This is perhaps because few libraries have developed sufficiently sophisticated cost accounting systems to enable them to state with certainty just how much they do invest annually in their interlibrary loan operations. Occasional ad hoc studies however, mostly of the "time and motion" type, have revealed discomfittingly high costs of even the simple operations of identifying and retrieving an item requested for interlibrary loan; of recording, wrapping, and shipping it; and finally of discharging and replacing it on the shelf when it is returned. Indirect costs such as internal and external administrative overhead, personnel development costs, and physical maintenance have seldom been considered. ${ }^{4}$ In any final analysis, moreover, still other factors ought also to be calculated into any accurate determination of total cost, such as the value of the expertise that went into the original selection of the title, an appropriate share of the original purchase and processing costs of the volume, and a portion of the cost of preserving it over its lifetime.

Some have estimated the total cost of a single interlibrary loan to be as high as $\$ 8$ within the lending institution alone. If this figure is assumed to be approximately accurate, it may be seen that a library that lends 5,000 more titles annually than it borrows is spending $\$ 40,000$ a year in service not to patrons from within its own supporting constituency but to other institutions entirely. Indeed some large libraries have estimated that they are spending in excess of $\$ 100,000$ per year on interlibrary lending more than they are benefiting from it. The best-willed institution on earth cannot long afford to carry such a burden. Indeed there is a troubling moral question here as to whether an administrator of a large library, especially a private library, may not be violating his responsibilities as the steward of his institution's bibliothecal assets when he allows this kind of dissipation to occur at all.

A glimmering recognition of this dilemma is now beginning to emerge on 
a few fronts. Two of the fifty states have recently implemented programs wherein the libraries within them that are primarily lenders are paid from state funds for lending to other libraries within the state. There is also talk of developing such a system on a national level. A national program would be infinitely better than local or regional programs because reader needs are not respecters of geographical or political boundaries. There is no logic, for example, to the present situation wherein Columbia University is reimbursed $\$ 4.50$ by the state of New York for a loan to the library at Skidmore College when it renders the same service in the same day to the library at Swarthmore completely free because the latter is located in Pennsylvania. Concurrent with discussion of a national plan, there are also discussions taking place among a number of large private libraries about the possibility of establishing a standard charge for all interlibrary loans, whether to be reimbursed by a state program, a national program, a borrowing library, or the ultimate recipient of the service-the patron who finally receives the book in the borrowing library.

Clearly this ferment of activity is leading somewhere, but no one is as yet prepared to predict just where. There are troublesome questions involved in any pay-as-you-go interlibrary loan program that need first to be resolved. One such question is "Who should pay?" Certain trends on the national scene seem to be toward letting such charges fall where the benefit is derived-namely in this case on the individual scholar for whom the book is borrowed. Not only does such an arrangement seem to satisfy neatly the current management quest for accountability, but it also relieves fear in some quarters of a user taking advantage of the system-for example, of someone promiscuously requesting twenty loans where one might do since the state or the library rather than the user is paying the cost. Experience with state-reimbursed loans, however, in New Jersey and New York seem thus far to indicate little need for fear on this score. This view seems also to have been fortified a decade ago when most libraries discontinued passing on to their users the postage charges incurred on their behalf in interlibrary borrowings.

Another question that would need to be resolved in any paid interlibrary loan system is whether or not the present Interlibrary Loan Code would continue to be adequate or would have to be revised. Would borrowings become permissible for undergraduates, a practice currently discouraged by the Code but allowed under New York State's NYSILL plan at state cost? Does the ability of a college library to borrow books for its undergraduates hinder its own natural growth rate? Perhaps. On the other hand, the line separating undergraduate instruction and research from work on the graduate level becomes less distinct daily. Maybe it has become meaningless.

Another troublesome moral problem is determining the proprietary rights of a paid borrower in the material he seeks. As long as interlibrary loan remains free there is no question but that service will be made available to him after all local needs for the same material have been fulfilled. Will a paying borrower actually purchase a share of access to the material he borrows equal to that of the local patron, or does he continue to gain only extraordinary access after local needs are met? If the latter, he presumably should be charged somewhat less than the cost to the local institution of "first-class" access.

How should an appropriate lending fee be determined? The most rational answer would probably be based on a cost accounting effort-namely the total cost of performing the transaction. Another approach might be for a lending 
institution to recalculate its rates annually simply by dividing the total library operating expenditure by the total number of circulations with the quotient serving as the unit charge for each interlibrary loan during the subsequent twelve months. Some librarians feel (and this concept is incorporated into New York State's program) that an equitably paid interlibrary loan system should involve two fees: one for receiving and attempting to fill an interlibrary loan request, and another for actual success in delivering the needed volume. Certainly there is some sound logic in having two fees.

These concepts are based upon the idea that each lending library would cost out its own operations and settle upon its own schedule of charges. There is some logic behind this scheme in that every library's costs are unique unto itself and should be fully reimbursed under any truly equitable program. Yet variant price schedules would create what would in effect be a chaotic market wherein borrowers would be inclined to "shop around" for the best price. Strong arguments seem therefore to militate in favor of one standard national price for interlibrary loan, perhaps based upon average costs in a sample of lending libraries, periodically reviewed.

Another complication lies in the way of implementing anything other than a nationally-funded program of interlibrary loan: the enormous overhead cost to the lending institution of maintaining separate accounts for each of its borrowing institutions, of rendering periodic invoices, conducting correspondence, collecting and depositing, writing off bad debts, and other commercial paraphernalia. Present state programs permit one central billing, made periodically to the appropriate state agency, and the receipt and crediting of one periodic check, thereby vastly facilitating the paper work involved in a paid interlibrary loan program.

Another possible method of mitigating the above difficulty might be the use of a nationally recognized interlibrary loan scrip of the kind proposed several years ago for purchasing photocopies. Such coupons could be purchased by libraries from a national agency and one sent accompanying each interlibrary loan request. Whenever a library that lends more than it borrows accumulates a superabundance of coupons, it could return them to the national agency in exchange for face value reimbursement. Local accounting requirements, of course, might in some institutions hamper efforts to get these reimbursements credited where they can be best used by the library.

A very substantial problem in the way of any priced interlibrary loan program is its relation to photocopy pricing schedules. Of the many factors enumerated above as making up the real costs of interlibrary loan service, all are exactly the same for meeting a photocopy request, in addition of course to the actual costs of making the copy. Thus if, for the sake of discussion, the hypothetical $\$ 8$ handling cost for interlibrary loan is held to be valid, then a similar handling charge would seem to be warranted in processing photocopy. An amount in that range is considerably greater than is presently being charged by any library in the country. If all charges were the same, of course, most large libraries would probably prefer to furnish photocopy in lieu of loan because their materials normally would not need to be off the shelf as long. Some small libraries also would for the same price probably prefer photocopy because they can retain the purchased piece to augment their collections against possible future need. Presumably photocopy charges to off-the-street patrons in large libraries would also be 
substantially influenced upward by any such revamping of the interlibraryloan/photocopy structure.

At any rate, it is clear that any program of paid interlibrary loan, whether nationally or locally funded, will bring with it a host of complications. The number of interlibrary loans would doubtless be vastly reduced because of the resulting relocation of their actual cost from the supplier to the user. Coming at a time when there is growing desire to free up rather than restrict the flow of the materials of scholarship, any such discussion is sure to elicit a spate of bad publicity for the large libraries that seem to favor it. Unless it is widely and clearly understood, it would likely be a very unpopular cause. Yet it might lead to salutary widerspread recognition of the very high costs of library services in support of advanced studies-a recognition that is certainly long overdue. Careful groundwork appears to be called for before such a program can be initiated.

\section{REFERENCES}

1. There are few proven data to confirm such an estimate. Sarah K. Thomson, however, in her D.L.S. thesis submitted at Columbia University in 1967 and entitled "General Interlibrary Loan Services in Major Academic Libraries in the United States," reported that 69 percent of all academic loans in the nation were made by sixty-three libraries.

2. Interlibrary lending by academic libraries doubled between 1965/66 and 1969/70 with 66 percent of the increase occurring in libraries holding more than a half million volumes. ILL traffic is expected to increase by a like amount again by $1974 / 75$. Vernon E. Palmour et al., A Study of the Characteristics, Costs, and Magnitude of Interlibrary Loans in Academic Libraries (Rockville, Md.: Westat, Inc., Sept. 1971), p. 55.

3. A fascinating method of quantifying this accumulating inequity in large libraries is reported by R. H. Blackburn, "Of Mice and Lions and Battleships and Interlibrary Things," IPLO Quarterly 13:68-79 (Oct. 1971). Utilizing Lanchester's Theory of Combat, he likens ILL requests to naval salvos, wherein we "imagine one blue battle- ship in an engagement with two green ships. If we assume all three ships to be of equal size and speed and firepower, each able to fire one broadside per minute, then the blue ship will be shot at twice a minute but each green ship only once in two minutes: the advantage of the green ships, and the relative hazard sustained by the blue, is therefore four to one. In the same way, three ships against one would have an advantage of nine to one."

4. Palmour, A Study of . . , p. 14-15, 24 assumed "more or less arbitrarily" an internal overhead rate of 50 percent of direct labor costs in arriving at its average lending costs for large academic libraries amounting to $\$ 2.12$ per unfilled loan request and $\$ 4.67$ for a filled loan request. Institutional overhead outside the library did not figure in these calculations, nor did the considerations raised later in the present paper. Consequently, Palmour pointed out, "the cost estimates given are almost surely underestimates of the true costs of interlibrary loan." Many librarians in large libraries will doubtless agree. 